\title{
経口摂取困難な脳卒中症例において栄養量需給管理システム $\lceil$ NSTManager」を導入した効果
}

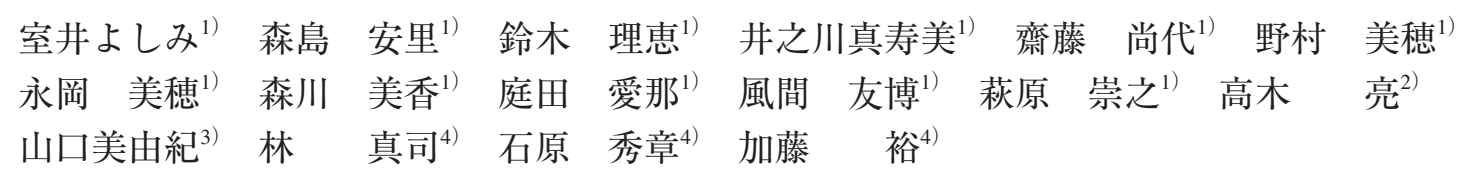

要旨：【目的】入院初期に意識障害や燕下障害などにより経口摂取困難な脳卒中患者に, 当院独自 の栄養量需給管理システム「NSTManager」の有用性を検討した.【方法】対象は急性期脳卒中症例で, 入院 3 日目の段階で GCS 12 点以下または食事摂取量が 7 割未満で, 28 日間連続観察可能な症例と した. 同システムの導入前 (対照群，30症例) と導入後 (NSTManager 群, 39 症例) とで, 入院後の栄 養状態，エネルギー量充足率，絶食期間，消化管有害事象を比較検討した.【結果】NSTManager 群 は, 対照群と比較して, 絶食期間の短縮 ( $\mathrm{p}=0.00022)$, 消化管有害事象の減少 $(\mathrm{p}=0.019)$, 体重変化率 の制御 $(\mathrm{p}=0.032)$ が有意に得られた。 また，入院 $21 ， 28$ 日目のエネルギー量充足率が有意に高かった ( $\mathrm{p}=0.027, \mathrm{p}=0.019)$.【結論】脳卒中患者に NSTManager を使用した栄養管理は有用である.

Key words: acute stroke, unable to orally ingest food, NSTManager, nutritional supply-demand control system

\section{背景および目的}

脳卒中では, 意識障害, 嚥下障害, 誤嚥, 中枢性嘔 吐，長期臥床による腸管麻痺，うつなどの精神的因子な ど，極めて多くの栄養摂取阻害要因が関与し，これまで にも患者の栄養状態と日常生活動作 (activities of daily living: ADL) などの予後との関連が数多く報告されてき た $^{1-3)}$. 脳卒中急性期病棟から回復期リハビリテーショ ン病棟への転棟時における栄養障害有病率は 43.5 $82 \%$ にも及ぶとされており ${ }^{1-3)}$, 治療進度に伴うリハビリ テーション (以後, リハビリ)強度の変化や身体活動の状 況に合わせた厳密な栄養管理が必要とされている

我々は, 入院初期において意識障害や讌下障害などに より経口摂取できない脳卒中患者を対象に, 当院独自の 栄養量需給管理システム「Nutrition Support Team Manager （NSTManager）」を運用し，その有用性を検討した。

\footnotetext{
1)社会医療法人至仁会圈央所沢病院看護部

2) 社会医療法人至仁会圈央所沢病院リハビリテーション科

3) 社会医療法人至仁会圈央所沢病院栄養科

4)社会医療法人至仁会圈央所沢病院脳神経外科 (2019 年 8 月 27 日受付, 2019 年 12 月 4 日受理) doi: $10.3995 /$ jstroke. 10760
}

\section{対象と方法}

対象は, 当院の Stroke Care Unitに入院した急性期脳 卒中症例 (一過性脳虚血発作を除く脳梗塞, 内因性脳出 血および内因性くも膜下出血）とした， その内，入院 3 日目の段階で Glasgow Coma Scale (GCS) 12 点以下, ま たは 1 日 3 食全量提供でない症例, 1 日 3 食全量提供で も摂取量が 7 割未満の症例とした. システム導入前の 2015 年 3 月〜 2016 年 2 月に入院した同条件の症例を対 照群，システム導入後の 2017 年 10 月〜2018 年 6 月に 入院した対象症例を NSTManager 群として比較検討し た。なお, データ久損, 輸血・血液製剤使用, Body Mass Index (BMI) $25 \mathrm{~kg} / \mathrm{m}^{2}$ 以上の肥満症例 ${ }^{8)}$, 他疾患で転科と なった症例, 糖尿病, 血液・腹膜透析を導入している症 例は除外し，28日間連続観察可能な症例とした。

NSTManager は，栄養障害のリスクがある症例を見落 とすことがないよう導入した，当院では，これまでも入 院時栄養スクリーニングの実施や病態に合わせた栄養投 与方法の検討を行い, 食事内容や経管栄養剂, 輸液の調 整などを行っていた。 しかし，意識障害や嚥下障害など で, 経口による栄養補給が困難な症例では, 栄養状態の 低下がみられていた，また，個々の体格や，疾患侵襲， 活動状況などを考慮した必要エネルギー量や, 経口・経 


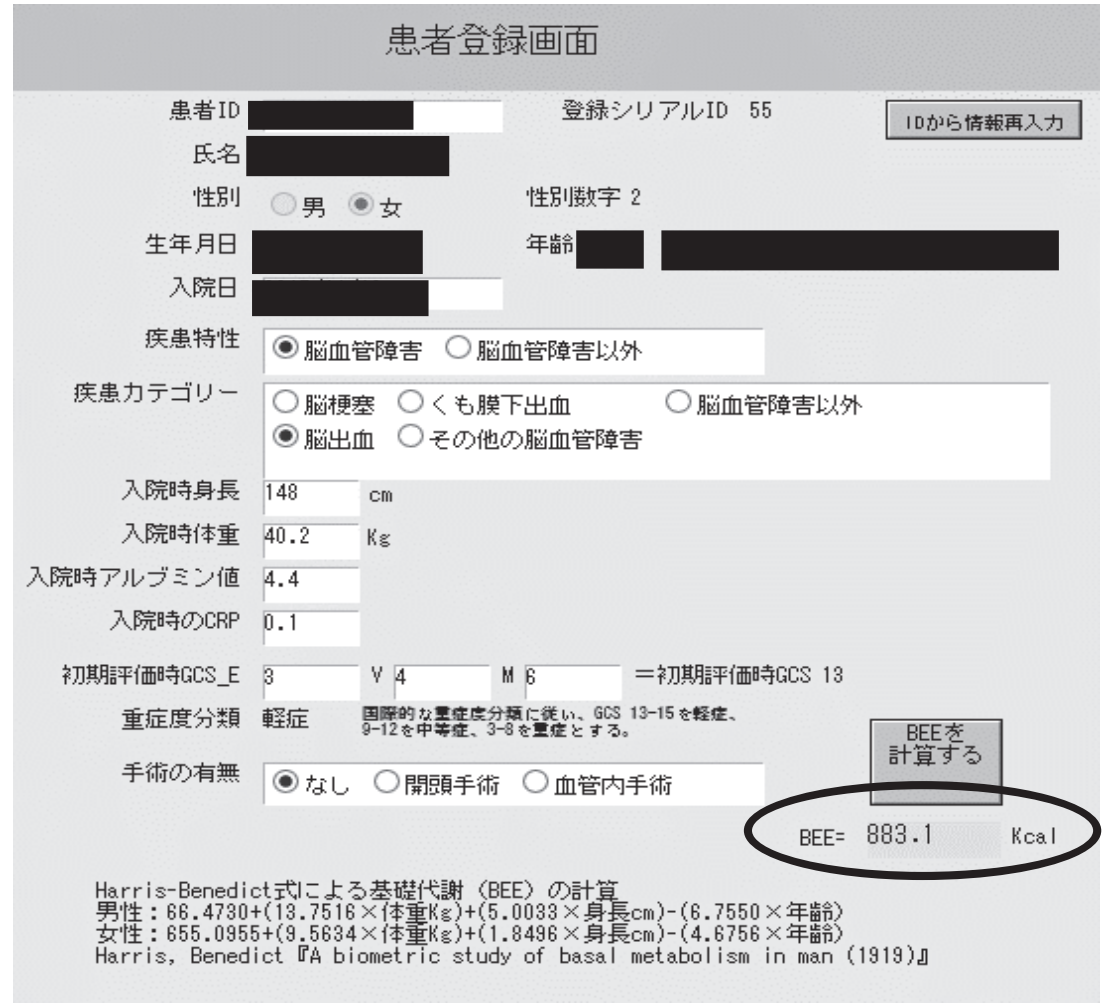

Fig. 1 NSTManager 初期画面 対象の基本情報を入力すると, Harris-Benedict 式による基礎代謝エネルギー量が表示される。
管栄養・輸液を含めた総摂取エネルギー量の計算は専門 的知識を要すが，急性期から亜急性期では変動が多く, 当院では, 多くの症例に高頻度で実施することは困難で あった。そこで，これら栄養需給量の計算を簡便に，か つ高頻度に行い，栄養介入できるようにした。

システムに性別・年齢・身長・体重を入力すると, Harris-Benedict の式9) を用いた基礎代謝エネルギー量 (basal energy expenditure: BEE) が自動計算される(Fig. 1)。総エネルギー消費量 (total energy expenditure: TEE) は, BEEに活動係数とストレス係数を乗じて算出し

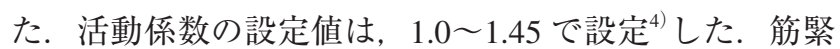
張艺進状態や不随意運動は運動によるエネルギー消費量 が増加し, 反対に弛緩性麻痺の場合は筋肉でのエネル ギー消費量が減少することから，筋緊張・不随意運動・ 振戦がある状態では +0.1 , 筋緊張低下・弛緩状態の場 合は -0.1 を加減算した ${ }^{10)}$ 。 ストレス係数には手術侵 襲, 疾患重症度, 体温を用いた。既報告では, コイル塞 栓術後の安静時エネルギー代謝量 (resting energy expenditure: REE) はBEEの 1.12 に及んでいる ${ }^{11)}$. そのため当院 では, 血管内治療症例は 1.1 , より侵襲のある開頭術で は 1.2 を加算した。 また, 脳卒中発症後の REE は BEE の 1.1 から 1.3 にも立進するという知見がある ${ }^{12-15)}$ が, 重症度など具体的な明示はない. そのため, 日本神経外 傷学会の定める GCS による重症度分類 ${ }^{16)}$ を基準とし
て，入院 3 日目の GCS 点数で設定した。 また，BEEに 影響する体温 ${ }^{17)}$ も加味した。各計算式や設定值は，Fig， 2 に示す。摂取エネルギー量は，点滴・経管栄養剂・食 事からのエネルギー量とし, 点滴や経管栄養剤は種類を 選択して投与量を入力し, 経口食は 1 日の提供カロリー 量 $(\mathrm{kcal})$ を主食と副食で分け，実際の摂取量を 10 段階 で評価して入力する。これらによって, エネルギー量充 足率が表示される。評価日には体重測定を行い，加えて 最新の血清 Albumin 值 (以後, Alb 值) も入力すると, 最 終的に, TEE, 総摂取エネルギー量, エネルギー量充足 率, 入院時と比較した体重・Alb 值の変化值が表示され る(Fig. 3). 評価入力は, 入院 3，5，7 日目，以降 7 日 毎28日目まで評価日担当の看護師が行い, 評価結果 は, 電子カルテ上で医師に報告した。 NSTManager は医 師と共に作成し, 導入に際しては各病棟 NST 委員や師 長・主任の協力を得，また，食事のカロリー表記につい ては栄養科, 体重測定に関してはリハビリ科の協力も得 た.

診療録から，基本情報〔年齢，性別，発症日を 1 日と した来院までの日数, 主疾患分類, 既往歴(高血圧症, 脂質異常症, 心房細動, 心不全の有無), 生活歴(喫煙 歴, 飲酒歴), 入院時 BMI, Alb 值, 総リンパ球数 (total lymphocyte count: TLC), 血清 C 反応性蛋白濃度 (C-reactive protein: CRP), 入院 3 日目の GCS, 初期評価 Barthel 


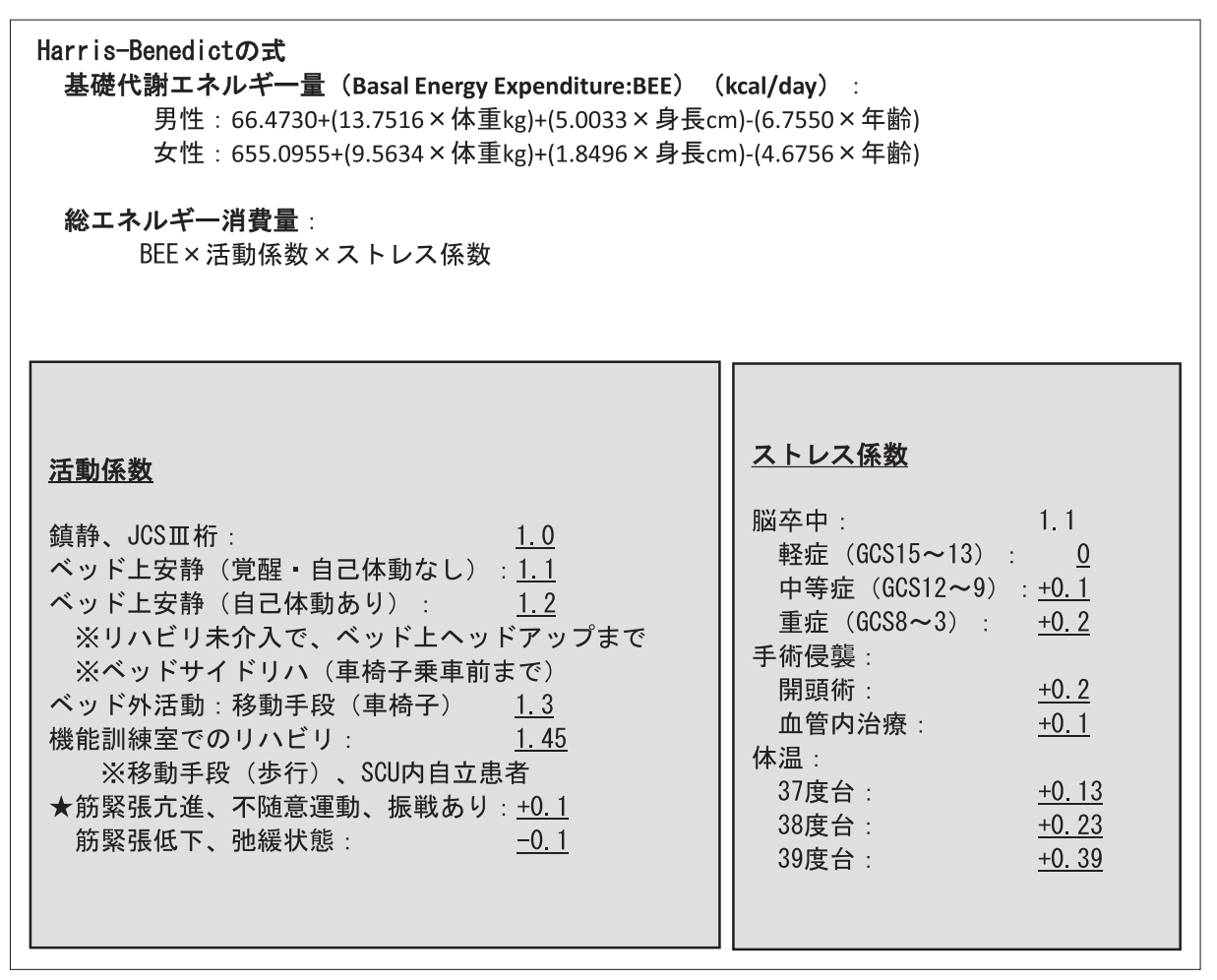

Fig. 2 Harris-Benedict による基礎代 謝量推定式と活動係数・ス卜 レス係数設定值

活動係数には筋緊張等も加味し，ス トレス係数には重症度, 手術侵襲, 体温を用いた。

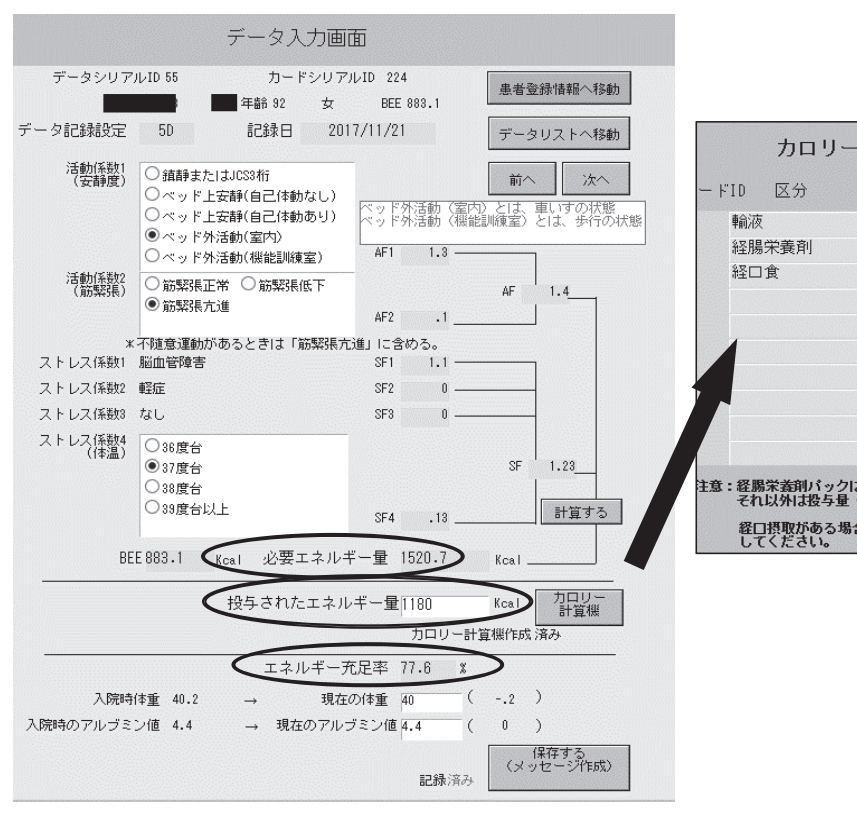

Fig. 3 NSTManager 詳細入力画面 活動係数とストレス係数を選択すると TEEが表示され，摂取 エネルギー量の入力も行うと充足率が表示される.

$\operatorname{Index}(\mathrm{BI})$ ]，入院から 7 日毎 28 日目までの TEE，実際 の総摂取エネルギー量, 経口摂取の有無, 入院 28 日後 の Alb 值と TLC, 体重, BI, 絶食期間, 消化器症状 を, NSTManager 群は前向きに, 対照群は後方視的に データ収集した．主疾患群分類は診断群分類 Diagnosis Procedure Combination(DPC) による分類とした. 高血圧 症は既往歴の聴取・降圧剤の服用と定義し, 脂質異常症
は既往歴の聴取・高脂血症治療薬の服用・LDL コレス テロール值 $140 \mathrm{mg} / \mathrm{dl}$ 以上, HDLコレステロール值 $40 \mathrm{mg} / \mathrm{dl}$ 以下, 中性脂肪が $150 \mathrm{mg} / \mathrm{dl}$ 以上と定義, 心房 細動は 12 誘導心電図や 3 点心電図モニター, 24 時間 Holter 心電図で診断し, 心不全は, 心不全症状, 心不全 を示す検査所見, 心不全に対する薬物治療中のいずれか を満たす場合と定義した。契煙や飲酒歴は本人や家族に 聴取した。CRPは，入院日から入院 28 日目までの平均 值とした。 TEEに対する総摂取エネルギー量の割合を エネルギー量充足率とし, 入院後 7 日毎の值を検討し た。また，入院後末梢静脈栄養から移行した栄養投与経 路を経口摂取の可否で分け，エネルギー量充足率を検討 した. 入院 28 日後の栄養状態変化として, Alb・TLC 
Table 1 対象の基本情報

\begin{tabular}{|c|c|c|c|c|}
\hline & & $\begin{array}{l}\text { NSTManager 群 } \\
\quad(\mathrm{n}=39)\end{array}$ & $\begin{array}{l}\text { 対照群 } \\
(\mathrm{n}=30)\end{array}$ & $\mathrm{P}$ 值 \\
\hline \multicolumn{2}{|c|}{ 年齢, 中央值 (IQR) } & $78(70-84)$ & $80(64-86)$ & 0.6 \\
\hline \multicolumn{2}{|l|}{ 性別 (男：女) } & $17: 22$ & $15: 15$ & 0.63 \\
\hline \multicolumn{2}{|c|}{$\begin{array}{c}\text { 発症から来院までの日数 }(\text { 日) } \\
\text { 中央值 }(\mathrm{IQR})\end{array}$} & $1(1-2)$ & $1(1-1)$ & 0.21 \\
\hline \multicolumn{2}{|c|}{ 疾患分類, n(\%) } & & & 0.56 \\
\hline \multicolumn{2}{|c|}{ 脳梗塞 } & $19(48.7)$ & $16(53.3)$ & \\
\hline \multicolumn{2}{|c|}{ 脳出血 } & $17(43.6)$ & $10(33.3)$ & \\
\hline \multicolumn{2}{|c|}{ くも膜下出血 } & $3(7.7)$ & $4(13.3)$ & \\
\hline \multirow[t]{4}{*}{ 既往歴, n(\%) } & 高血圧症 & $21(53.8)$ & $17(56.7)$ & 1.00 \\
\hline & 脂質異常症 & $17(43.6)$ & $15(50.0)$ & 0.63 \\
\hline & 心房細動 & $9(23.1)$ & $7(23.3)$ & 1.00 \\
\hline & 心不全 & 4 & 3 & \\
\hline \multirow[t]{2}{*}{ 生活歴, n(\%) } & 喫煙歴 & $9(23.1)$ & $10(33.3)$ & 0.42 \\
\hline & 飲酒歴 & $14(35.9)$ & $9(30)$ & 0.79 \\
\hline \multicolumn{2}{|c|}{$\begin{array}{l}\mathrm{BMI}\left(\mathrm{kg} / \mathrm{m}^{2}\right) \\
\quad \text { 平均值 } \pm \mathrm{SD}\end{array}$} & $20.7 \pm 3.01$ & $21.4 \pm 3.30$ & 0.36 \\
\hline \multicolumn{2}{|c|}{$\begin{array}{c}\text { 入院時 } \mathrm{Alb} \text { 值 }(\mathrm{g} / \mathrm{dl}) \\
\text { 平均值 } \pm \mathrm{SD}\end{array}$} & $4.15 \pm 0.47$ & $3.94 \pm 0.5$ & 0.074 \\
\hline \multicolumn{2}{|c|}{$\begin{array}{c}\text { 入院時 } \mathrm{TLC}(/ \mu \mathrm{l}) \\
\text { 中央值 }(\mathrm{IQR})\end{array}$} & $1273.7(807.6-1809.2)$ & $1152.9(844.0-1978.6)$ & 0.94 \\
\hline \multicolumn{2}{|c|}{$\begin{array}{r}\mathrm{CRP} \text { 平均值 }(\mathrm{mg} / \mathrm{dl}), \\
\text { 中央值 }(\mathrm{IQR})\end{array}$} & $1.32(0.62-4.53)$ & $3.58(1.55-4.43)$ & 0.38 \\
\hline \multicolumn{2}{|c|}{$\begin{array}{r}\text { 入院 } 3 \text { 日目の } \mathrm{GCS} \\
\text { 中央值 }(\mathrm{IQR})\end{array}$} & $12(9-14)$ & $13(9-15)$ & 0.42 \\
\hline \multicolumn{2}{|c|}{$\begin{array}{l}\text { 初期評価 BI } \\
\text { 中央值 (IQR) }\end{array}$} & $0(0-65)$ & $0(0-40)$ & 0.94 \\
\hline
\end{tabular}

IQR: interquartile range, BMI: Body Mass Index, SD: standard deviation, Alb: albumin, TLC: total lymphocyte count, CRP: C-reactive protein, GCS: Glasgow Coma Scale, BI: Barthel Index

変化值( 入院 28 日後の值から入院時の值を減じて算 出), 体重変化率(入院 28 日目の值から入院時の值を減 じ，それを入院時の值で除し，100を乗じた值）， BI 利 得点数(入院 28 日後の值から初期評価の值を減じて算 出）を検討した。絶食期間は，入院初日を 0 日として, 経口摂取または経管栄養投与開始までの日数と定義し た，消化器症状は，便秘，下㾥，嘔気・嘔吐の有無につ いて検討した．いずれも消化管使用開始後とし，便秘は 3 日間排便がなく摘便や薬剤使用等の対処を要した場 合，下痢はブリストル便性状スケール ${ }^{18)}$ を用い，6また は７にあたる排便がみられ，薬郕使用等の対処を要した 場合, 嘔気・嘔吐は症状があった場合や，薬剤使用等の 対処を要した場合と定義した。薬剤使用や処置を必要と せず，定期的にブリストル便性状スケール 5 以下の排便
が得られていた状態を問題なしと定義した。

統計解析は，全てにおいて正規性の検定では ShapiroWilk 検定を行った２２群間の比較では $\mathrm{t}$ 検定もしくは Mann-Whitney’s U 検定を用い，群間での頻度 $(\%) の$ 比較 は Fisherの正確検定を用いて検定した。統計学的解析は EZR Version $1.37^{19)}$ を用い，統計学的有意水準は $5 \%$ とし た.

本研究は, 圈央所沢病院倫理委員会の承認を得て実施 した(承認番号 2017001).

\section{結 果}

NSTManager 群は 39 症例, 対照群は 30 症例であっ た. Table 1 に基本情報の結果を示した。平均年齝 $75.7 \pm 12.7$ 歳，女性 37 例，発症から来院までの期間は平 
Table 2 入院 28 日後の結果

\begin{tabular}{|c|c|c|c|}
\hline & $\begin{array}{c}\text { NSTManager 群 } \\
\quad(\mathrm{n}=39)\end{array}$ & $\begin{array}{l}\text { 対照群 } \\
(\mathrm{n}=30)\end{array}$ & $\mathrm{P}$ 值 \\
\hline \multicolumn{4}{|l|}{$\begin{array}{l}\text { 充足率 }(\%) \\
\text { 平均值 } \pm \mathrm{SD}\end{array}$} \\
\hline day7 & $64.3 \pm 25.9$ & $66.0 \pm 22.0$ & 0.77 \\
\hline day14 & $76.5 \pm 16.7$ & $73.1 \pm 27.1$ & 0.25 \\
\hline day 21 & $80.0 \pm 21.2$ & $68.6 \pm 21.6$ & $0.027^{*}$ \\
\hline day 28 & $84.9 \pm 16.5$ & $74.5 \pm 18.2$ & $0.019^{*}$ \\
\hline \multicolumn{4}{|l|}{ 入院 28 日後の変化 } \\
\hline $\begin{array}{r}\text { 体重変化率 }(\%) \\
\text { 中央值 }(\mathrm{IQR})\end{array}$ & $-3(-5.6--0.2)$ & $-5.7(-8.3--2.1)$ & $0.032^{*}$ \\
\hline $\begin{array}{c}\mathrm{Alb} \text { 変化值 }(\mathrm{mg} / \mathrm{dl}) \\
\text { 平均值 } \pm \mathrm{SD}\end{array}$ & $-0.69 \pm 0.46$ & $-0.74 \pm 0.62$ & 0.63 \\
\hline $\begin{array}{r}\mathrm{TLC} \text { 変化值 }(/ \mu \mathrm{l}) \\
\text { 中央值 }(\mathrm{IQR})\end{array}$ & $68.4(-316.8-629.1)$ & $130.6(-594.6-57.0)$ & 0.91 \\
\hline $\begin{array}{c}\mathrm{BI} \text { 利得点数 (点) } \\
\text { 中央值 }(\mathrm{IQR})\end{array}$ & $30(0-52.5)$ & $10(0-40)$ & 0.25 \\
\hline $\begin{array}{l}\text { 絶食期間 (日) } \\
\text { 中央値 (IQR) }\end{array}$ & $2(0.5-3)$ & $5(2.2-8)$ & $0.00022^{* *}$ \\
\hline 消化器症状, n(\%) & & & $0.019^{*}$ \\
\hline 便秘 & $14(35.9)$ & $21(70.0)$ & \\
\hline 下痢 & $2(5.1)$ & $5(16.7)$ & \\
\hline 嘔気・嘔吐 & $0(0.0)$ & $1(3.3)$ & \\
\hline 問題なし & $14(35.9)$ & $3(10.0)$ & \\
\hline
\end{tabular}

SD: standard deviation, IQR: interquartile range, Alb: albumin, TLC: total lymphocyte count, BI: Barthel Index p $<0.05, \quad{ }^{* *} \mathrm{p}<0.01$

均 $1.5 \pm 1.0$ 日であった。疾患内訳は, 脳梗塞 35 例, 脳 出血 27 例, くも膜下出血 7 例であった. 入院時 BMI は, 平均 $21.0 \pm 3.1 \mathrm{~kg} / \mathrm{m}^{2}$ で, $\mathrm{Alb}$ 值は平均 $4.0 \pm 0.4 \mathrm{mg} / \mathrm{dl}$ であった。

年齢, 性別, 発症から来院までの日数, 主疾患分類, 既往歴(高血圧症, 脂質異常症, 心房細動, 心不全), 生 活歴(喫煙歴, 飲酒歷), 入院時 BMI, Alb 值, TLC, $\mathrm{CRP}$ 平均值, 入院 3 日目の GCS, BI の各項目におい て, 両群に有意な差は認めなかった。

入院 28 日目までの結果を Table 2 に示す. NSTManager 群と対照群で, エネルギー量充足率は入院 7 日目 (64.3\% vs. $66.0 \%, p=0.77), 14$ 日目 $(76.5 \%$ vs. $73.1 \%$, $\mathrm{p}=0.25)$ で有意差はなかったが, 21 日目 $(80.0 \%$ vs. $68.6 \%, \mathrm{p}=0.027), 28$ 日目 $(84.9 \%$ vs. $74.5 \%, \mathrm{p}=0.019)$ で NSTManager 群が有意に高かった。体重変化率 $(-3 \%$ vs. $-5.7 \%, \mathrm{p}=0.032)$ は NSTManager 群が有意に少なかっ た. Alb変化值 $(-0.69 \mathrm{mg} / \mathrm{dl}$ vs. $-0.74 \mathrm{mg} / \mathrm{dl}, \mathrm{p}=0.63)$,
TLC 変化值 (68.4/ $\mu \mathrm{l}$ vs. $130.6 / \mu \mathrm{l}, \mathrm{p}=0.91), \quad \mathrm{BI}$ 利得点数 (30 点 vs. 10 点, $\mathrm{p}=0.25$ ) は, 有意な差はみられなかっ た。絶食期間 ( 2 日 vs. 5 日， $\mathrm{p}=0.00022$ )は, NSTManager 群が有意に短縮していた。消化器症状では, 便秘 (35.9\% vs. $70 \%)$, 下㾥 $(5.1 \%$ vs. $16.7 \%)$, 嘔気・嘔吐 (0\% vs. $3.3 \%)$, 問題なし ( $35.9 \%$ vs. $10 \%)$ で，有意差を 認めた $(\mathrm{p}=0.019)$.

経口摂取の可否で分けたエネルギー量充足率は, 経口 摂取症例では, 各時点において両群間に有意差はなかっ た. 非経口摂取症例では, 入院 21,28 日目で, NSTManager 群が有意に上昇していた $(\mathrm{p}=0.0014, \mathrm{p}=0.01)$ (Table 3).

\section{考察}

NSTManagerの導入によって, 絶食期間の短縮, 消化 管有害事象の減少, エネルギー量充足率の上昇, 体重減 少率の制御が得られた。 
Table 3 経口摂取の可否によるエネルギー量充足率

\begin{tabular}{|c|c|c|c|c|c|c|}
\hline & \multicolumn{2}{|c|}{ 経口摂取可能症例 } & \multirow[b]{2}{*}{$\mathrm{P}$ 值 } & \multicolumn{2}{|c|}{ 非経口摂取症例 } & \multirow[b]{2}{*}{$\mathrm{P}$ 值 } \\
\hline & $\begin{array}{c}\text { NSTManager 群 } \\
\mathrm{n}=15\end{array}$ & $\begin{array}{c}\text { 対照群 } \\
\mathrm{n}=15\end{array}$ & & $\begin{array}{c}\text { NSTManager 群 } \\
n=24\end{array}$ & $\begin{array}{c}\text { 対照群 } \\
\text { n=20 }\end{array}$ & \\
\hline \multicolumn{7}{|c|}{$\begin{array}{l}\text { 充足率 }(\%) \\
\text { 平均值 } \pm \mathrm{SD}\end{array}$} \\
\hline day7 & $65.6 \pm 25.9$ & $76.5 \pm 25.1$ & 0.31 & $63.5 \pm 26.6$ & $60.8 \pm 18.9$ & 0.70 \\
\hline day 14 & $77 \pm 15.9$ & $81.2 \pm 31.1$ & 0.66 & $76.3 \pm 17.6$ & $69.1 \pm 24.9$ & 0.27 \\
\hline day 21 & $79.8 \pm 28.6$ & $80.7 \pm 23.2$ & 0.93 & $80.3 \pm 15.7$ & $62.6 \pm 18.6$ & $0.0014^{* *}$ \\
\hline day 28 & $87.2 \pm 16.1$ & $83.2 \pm 21.9$ & 0.60 & $83.5 \pm 17.1$ & $70.3 \pm 14.9$ & $0.01^{*}$ \\
\hline
\end{tabular}

SD: standard deviation ${ }^{*} \mathrm{p}<0.05, \quad{ }^{* *} \mathrm{p}<0.01$

これは, システムへの入力や数值化された評価結果に より, 治療担当者の栄養に関する意識改革がされ, 職種 間での情報共有・交換が増えたためと考えられる. 経管 栄養投与下の低体重脳卒中症例において, 栄養モニタリ ングを 1 回／週行った群は 1 回／月の群と比較して BMI 増加量が大きく, 機能的自立度評価表 (Functional Independence Measure: FIM)の点数が高いという報告が ある20)。また，低栄養リスクのある急性期脳卒中患者で は，個別に栄養ケアを行うと，ルーチンケアに比べて体 重減少がより制御され, Quality of Life (QOL) や握力が より改善したという報告もある ${ }^{21)}$. 今回, 有意差はない ものの, BI 利得点数の上昇もみられ, NSTManager の導 入は同様の効果があったと考える。しかし，急性期から 亜急性期における検討では, 特に侵襲や麻痺, 活動状況 変化による骨格筋変化や ${ }^{7,22,23)}$ ，侵襲・脳損傷などさま ざまな要因で体水分量の変化が存在する ${ }^{24)}$. そのため, 今後は体組成計などを用いた検討が必要と思われた。

また，本研究では，消化管有害事象の減少がみられ， これは絶食期間の短縮が影響したと考えられる。腸管の 使用は, 腸管粘膜萎縮を防止し, 腸管の吸収能が維持さ れる ${ }^{25)}$. 今回, 他関連因子の検討は行っていないため, 単に絶食期間の短縮による効果と言及することはできな いが, 消化管有害事象の減少により, 投与栄養の効果的 な栄養吸収，栄養量の漸増ができたと考えられる。

経口摂取の可否で分けた検討では, 入院当初から経口 摂取可能な症例ではエネルギー量充足率の上昇は僅かで あった. しかしそれは, 入院初期に経口摂取が少量で も, その後経口からの栄養量漸増が可能であったケース が多かったためと思われる. 非経口摂取症例において は，嚥下障害と栄養障害は関連するとの報告もあり ${ }^{26)}$, 当院でも, 早期の経管栄養開始や, 静脈栄養での補填と
いった介入を行い，エネルギー量充足率が上昇した，こ の結果から, NSTManager は非経口摂取症例に特に有効 な栄養管理システムであると思われた。

本研究の問題点として, NSTManager 導入前後の時期 が異なる 2 群を比較したものであるため, 厳密な比較検 討とは言い難いことが挙げられる。また，Alb 值は半減 期が 21 日であり，鋭敏性に欠けるため，今後は急性相 の栄養指標となる rapid turnover protein 等 ${ }^{27,28)}$ を用いた検 討が必要と思われた。

\section{結 論}

「脳卒中治療ガイドライン 2015」でも，低栄養は独立 した転帰不良因子となっている ${ }^{29)}$. 経口摂取困難な脳卒 中患者に対し，NSTManager 導入による栄養管理を実施 し，導入前と比較して亜急性期までの良好な栄養管理が 得られた。個々の患者特性に応じた積極的な栄養管理 は，脳卒中後の全身状態と QOL の改善に資する可能性 がある。

著者は, 日本脳卒中学会への COI 自己申告を完了し ており，本論文の発表に関して，開示すべきCOIはな い.

\section{参考文献}

1）西岡心大, 高山仁子, 渡邊美鈴ら：本邦回復期リハビリ テーション病棟入棟患者における栄養障害の実態と高齢 脳卒中患者における転帰，ADL帚結との関連．日静脈経 腸栄会誌 30: 1145-1151，2015

2）相良亜木子, 川上寿一，松本憲二ら：黇下障害を呈する 脳卒中患者のエネルギー摂取量と栄養状態が ADL に及ぼ す影響＼cjkstart回復期リハにおける検討。J Clin Rehabil 18: 179_ 182,2009

3）吉田貞夫：回復期リハビリテーション病棟に入院する高 
齢者の栄養状態とアウトカム．静脈経腸栄養 28: 10511056, 2013

4）若林秀隆：リハビリテーション栄養ハンドブック。東 京, 医歯薬出版, 2010,pp9-14, 95-97, 270-273

5）若林秀隆：リハビリテーションと臨床栄養. Jpn J Rehabil Med 48: 270-281, 2011

6）西岡心大：低栄養とリハビリテーション栄養管理の考え 方. 日静脈経腸栄会誌 31: 944-948, 2016

7）寺島秀夫, 只野惣介, 大河内信弘 : 各論 周術期を含め 侵襲下に抢けるエネルギー投与に関する理論的考え方. 静脈経腸栄養 24: 1027-1043, 2009

8）日本肥満学会編：肥満症診療ガイドライン 2016. 東京, ライフサイエンス出版, 2016, pp5

9) Harris JA, Benedict FG : A biometric study of basal metabolism in man. Washington DC, Carnegie Institute of Washington, 1919

10）一般社団法人日本病態栄養学会編: 改訂第 4 版 認定 病態栄養専門師のための病態栄養ガイドブック.大阪, メディカルレビュー社, 2013, pp67, 309-310

11) Nagano A, Yamada $Y$, Miyake H, et al: Increased resting energy expenditure after endovascular coiling for subarachnoid hemorrhage. J Stroke Cerebrovasc Dis 25: 813-818, 2016

12) Finestone HM, Greene-Finestone LS, Foley NC, et al: Measuring longitudinally the metabolic demands of stroke patients: resting energy expenditure is not elevated. Stroke 34: 502-507, 2003

13) Kawakami M, Liu M, Wada A, et al: Resting energy expenditure in patients with stroke during the subacute phases - relationships with stroke types, location, severity of paresis, and activities of daily living. Cerebrovasc Dis 39: 170-175, 2015

14）中澤明紀, 佐竹將宏, 木元裕介ら：急性期脳卒中患者の 基本的姿勢における呼吸代謝に関する検討. 理学療法学 44: 415-425, 2017

15) Esper DH, Coplin WM, Carhuapoma JR: Energy expenditure in patients with nontraumatic intracranial hemorrhage. JPEN J Parenter Enteral Nutr 30: 71-75, 2006

16）日本神経外傷学会編：重症頭部外傷治療・管理のガイド ライン。東京, 医学書院, 2001, pp14-15
17）細谷憲政：今なぜエネルギー代謝か. 東京, 第一出版, 2000, pp8

18) Lewis SJ, Heaton KW: Stool form scale as a useful guide to intestinal transit time. Scand J Gastroenterol 32: 920-924, 1997

19) Kanda Y: Investigation of the freely available easy-to-use software 'EZR' for medical statistics. Bone Marrow Transplant 48: 452-458, 2013

20）西岡心大，菅原英和，高山仁子ら：経管栄養管理下の低 体重脳卒中患者における栄養モニタリング頻度と体重増 加および ADL 向上との関連. Jpn J Compr Rehabil Sci 9: 3-10, 2018

21) Ha L, Hauge T, Spenning AB, et al: Individual, nutritional support prevents undernutrition, increases muscle strength and improves QoL among elderly at nutritional risk hospitalized for acute stroke: a randomized, controlled trial. Clin Nutr 29: $567-$ 573,2010

22）阿部千恵, 村上賢一, 藤澤宏幸 : 急性期脳卒中片麻痺患 者における筋厚の経時的変化. 理学療法学 43: 136-142, 2016

23）近藤克則，太田正：脳卒中早期リハビリテーション患者 の下肢筋断面積の経時的変化. リ八医 34: 129-133, 1997

24）太田 樹, 内田俊也：水・ナトリウム代謝異常. 日内会 誌 104: 906-916, 2015

25）巽 博臣，升田好樹：栄養管理のポイント。医事新報 4866: 57-64, 2017

26）松尾晴代, 吉村芳弘, 石崎直樹ら：急性期病院高齢患者 における摂食與下障害スクリーニング質問紙票 EAT-10 で 評価した嚥下障害と低栄養の関連，日静脈経腸栄会誌 31 : 1141-1146, 2016

27）安井苑子, 齋藤 裕, 演田康弘：Rapid turnover protein 值 とその解釈. 臨栄 126: 720-725, 2015

28）日本静脈経腸栄養学会編：栄養療法の治療効果のモ二夕 リング 静脈経腸栄養ガイドライン 第 3 版. 東京, 照 林社, 2013, pp149-152

29）日本脳卒中学会, 脳卒中ガイドライン委員会編 : 脳卒中 一般. 脳卒中治療ガイドライン 2015. 東京, 協和企画, 2015, pp8-9 


\section{Abstract \\ Effects of the nutritional supply-demand control system 'NSTManager' on stroke patients who are unable to orally ingest food}

Yoshimi Muroi, ${ }^{1)}$ Anri Morishima, ${ }^{1)}$ Rie Suzuki, ${ }^{1)}$ Masumi Inokawa, ${ }^{1)}$ Hisayo Saitoh, ${ }^{1)}$ Miho Nomura, ${ }^{1)}$ Miho Nagaoka, ${ }^{1)}$ Mika Morikawa, ${ }^{1)}$ Aina Niwata, ${ }^{1)}$ Tomohiro Kazama, ${ }^{1)}$ Takayuki Hagiwara, ${ }^{1)}$ Ryo Takagi, ${ }^{2)}$ Miyuki Yamaguchi, ${ }^{3)}$ Shinji Hayashi, M.D., Ph.D., Hideaki Ishihara, M.D., Ph.D., ${ }^{4)}$ and Hiroshi Katoh, M.D., Ph.D. ${ }^{4)}$

${ }^{1)}$ Department of Nursing, Social Medical Corporation Shijinkai Ken-o-Tokorozawa Hospital ${ }^{2)}$ Department of Rehabilitation, Social Medical Corporation Shijinkai Ken-o-Tokorozawa Hospital

${ }^{3)}$ Department of Nutrition, Social Medical Corporation Shijinkai Ken-o-Tokorozawa Hospital ${ }^{4)}$ Department of Neurosurgery, Social Medical Corporation Shijinkai Ken-o-Tokorozawa Hospital

Background and Purpose: The aim of this study is to evaluate the utility of our unique nutritional supply-demand control system, Nutrition Support Team Manager (NSTManager), in stroke patients who were unable to orally consume food due to disturbances of consciousness or dysphagia early in their hospitalization. Methods: Acute stroke patients with a Glasgow Coma Scale score of $\leq 12$ or who had a meal intake of $<70 \%$ on hospitalization day 3 and who could be observed for 28 consecutive days were included. Nutritional status, energy intake, fasting periods, and adverse gastrointestinal events were evaluated and compared between before (control group, $n=30$ ) and after (NSTManager group, $n=39)$ NSTManager introduction. Results: Significant reduction of fasting periods ( $\mathrm{p}=0.00022)$, adverse gastrointestinal events $(\mathrm{p}=0.019)$, and changes in body weight $(\mathrm{p}=0.032)$ were noted in the NSTManager group in contrast to the control group. Higher significant energy intake (day 21, $\mathrm{p}=0.027$ and day $28, \mathrm{p}=0.019$, respectively) were seen in the NSTManager group than in the control group on hospitalization days 21 and 28. Conclusion: Nutritional support using NSTManager was beneficial for patients recovering from strokes.

Key words: acute stroke, unable to orally ingest food, NSTManager, nutritional supply-demand control system 